\title{
The Relationship between duration Hypertension with Cognitive Function in Elderly at Health Care II West Denpasar area
}

\author{
Putu Indah Budi Apsari ${ }^{1}$, Putu Sutisna ${ }^{1^{*}}$, Stephany Angelia ${ }^{1}$ \\ ${ }^{1}$ Faculty of Medicine and Health Sciences Warmadewa University \\ *psutisna@yahoo.com
}

\begin{abstract}
Hypertension is a condition in which a person's systolic blood pressure over $140 \mathrm{~mm} \mathrm{Hg}$ and or diastolic blood pressure over $90 \mathrm{mmHg}$. In Indonesia, 7-9\% of hypertensive patients have cognitive dysfunction. This study aimed to determine the relationship between duration of hypertension and cognitive function in elderly at Health Centre II West Denpasar area. This study used analytic cross sectional design with 71 elderly respondents over 60 years old selected by Consecutive Sampling from the elderly attending Posyandu (Comprehensive Health Care) program at Health Centre II West Denpasar. Secondary data were used taken from medical records in the Health Centre II West Denpasar. Instrument used in this study was Mini Mental State Examination. (MMSE). Data were analyzed statistically using univariate and bivariate analysis by Chi Square test. The results showed hypertension over 5 year was suffered by $68.9 \%$ respondents with decreased cognitive function, while hypertension under 5 year was suffered by $38.7 \%$ respondents with decreased cognitive function. There was a significant relationship between duration of hypertension and cognitive function in elderly.

Keyword : Relationship, Hypertension, Denpasar Area.
\end{abstract}

\section{Introduction}

Hypertension is often called the silent killer because in the early stages it is usually asymptomatic, so the patient does not feel until complications occur or cause death. Hypertension is one of the public health problems in Indonesia. According to the National Comitte Join Criteria (JNC 8) normal blood pressure is $<140 / 90 \mathrm{mmHg}$. [1] Based on data from the Bali Provincial Health Office (2015) hypertension is ranked second in 10 major diseases in patients at the Puskemas.[2] According to data from the Basic Health Research Ministry of Health of the Republic of Indonesia (2013), nationally $25.8 \%$ of Indonesia's population suffers from hypertension. [3] The incidence of hypertension in the elderly in Denpasar City is mostly found in Puskesmas II Denpasar Barat.[2] Globally, lifestyle changes play a major role in increasing the incidence of hypertension. Increasing age results in increased blood pressure, because arterial walls in the elderly experience thickening which results in the accumulation of collagen in the muscle layer, so that blood vessels narrow and stiff.[4] One complication of hypertension is the central nervous system which causes cognitive dysfunction.[1] Based on background above, the authors are interested in conducting research to determine the relationship between the duration of hypertension and cognitive function in the elderly in the working area of the Denpasar West Health Center II. 


\section{Method}

\subsection{Data Collection}

This study was an observational analytic study with a cross sectional approach to determine the relationship between the duration of hypertension and cognitive function in the elderly at Puskesmas II Denpasar Barat. The research was conducted at the Elderly Posyandu in the West Denpasar Health Center II working area. Samples or subjects of this study were elderly aged above 60 years with hypertension in the Posyandu for Elderly Working Areas Denpasar West Health Center II that fulfills the inclusion criteria and is not included in the exclusion criteria. Sampling was done by consecutive sampling method. Each respondent who fulfilled the inclusion criteria was included in the study until a certain period of time until the number of respondents was fulfilled. The data collected were primary data obtained by interviews using the Mini Mental State Examination (MMSE) test and secondary data obtained from the medical records of Puskesmas II Denpasar Barat. Data collection was carried out by visiting the Elderly Posyandu scheduled in the Denpasar West Health Center II Working Area. Respondents in this study were categorized into hypertension groups who had a systolic blood pressure above $140 \mathrm{mmHg}$ or diastolic blood pressure above $90 \mathrm{mmHg}$ were respondents with a hypertension duration of less than 5 years and respondents with longer hypertension for more than 5 years. Assessment of cognitive function is based on the number of scores interviewed regarding these five aspects in the Mini Mental State Examination (MMSE) Test. Cognitive function is stated to decrease if the respondent gets a score of less than 27 and cognitive functions are declared normal if the respondent scores 28-30.

\subsection{Data analysis}

The data obtained were analyzed by univariate and bivariate. Univariate analysis was conducted to determine the frequency distribution of respondents' characteristics. Bivariate analysis was performed using the chi square test to determine the relationship between the duration of hypertension and cognitive function. Significant assessment or meaningfulness of difference was measured at $p<0.05$. If $p$ value $<0.05$ means that there was a significant relationship between the independent variable and the dependent variable and if $p$ value $\geq 0.05$ means there is no meaningful relationship between the independent variable and the dependent variable.

\section{Results And Discussion}

Respondents in this study were 76 people. The sex of the respondents was predominantly women, namely 45 people (59.2\%) compared to men 31 people (40.8\%). Viewed from the age of 70-79 years, there are 39 people (51.3\%), while the age of $>80$ years is 17 people (22.4) and in the middle age group of 6069 years there are 20 people (26.3\%) Judging from the history of education, hypertension sufferers have more elementary education as many as 36 people (47.4\%), followed by junior high school education as many as 21 people (27.6\%), those with high school education as many as 18 people $(23.7 \%)$ and the rest in a small number of tertiary education was 1 person $(1.3 \%)$. 
Table 1. Characteristics of Respondents

\begin{tabular}{ccc}
\hline \multicolumn{1}{c}{ Variable } & Frequency & Percent (\%) \\
\hline $\begin{array}{l}\text { Gender } \\
\text { Male }\end{array}$ & 31 & \\
$\quad$ Female & 45 & 40.8 \\
Age (years) & & 59.2 \\
$\quad 60-69$ & 20 & \\
$70-79$ & 39 & 26.3 \\
$>80$ & 17 & 51.3 \\
Educational & & \\
$\quad$ Elementary school & & 22.4 \\
$\quad$ Junior high school & 36 & 47.4 \\
Senior high school & 21 & 27.6 \\
$\quad$ Bachelor degree & & \\
\hline
\end{tabular}

Table 2. Characteristics of Respondents by Length of Hypertension and Mini Mental State Test Results Examination (MMSE) $(\mathrm{n}=76)$

\begin{tabular}{lcc}
\hline \multicolumn{1}{c}{ Variable } & Frequency & Percent $(\%)$ \\
\hline $\begin{array}{l}\text { Duration of hypertension } \\
\quad>5 \text { years }\end{array}$ & 45 & \\
$\quad<5$ years & 31 & 60.5 \\
Result of MMSE & & 39.5 \\
$\quad$ Normal & 33 & \\
$\quad$ Decrease & 43 & 43.4 \\
\hline
\end{tabular}

Data on the distribution of respondents according to the duration of suffering from hypertension and the results of the MMSE test are presented in Table 2. More respondents with hypertension for more than 5 years, 45 people $(60.5 \%)$ compared to the duration of hypertension for less than 5 years 31 people (39.5\%). Obtained hypertension sufferers experienced a decline in cognitive function as many as 43 people $(56.6 \%)$ and hypertensive patients who did not experience a decline in cognitive or normal function as many as 33 people $(43.4 \%)$ (see Table 2 ).

Table 3. Relationship between the duration of hypertension and cognitive function in the elderly

\begin{tabular}{lcccc}
\hline \multicolumn{1}{c}{ Variable } & Normal N (\%) & Decrease N (\%) & P & R \\
\hline $\begin{array}{l}\text { Duration of } \\
\text { hypertension }\end{array}$ & & & & \\
$\begin{array}{l}>5 \text { years } \\
\text { <years }\end{array}$ & $14(31,1)$ & $31(68,9)$ & 0,009 & 0,287 \\
\hline
\end{tabular}

Table 3 showed 14 respondents $(31.1 \%)$ who suffer from hypertension more than 5 years have normal cognitive function and as many as 31 respondents $(68.9 \%)$ who suffer from hypertension more than 5 years have decreased cognitive function, while as many as 19 respondents $(61.3 \%)$ who suffer from hypertension for less than 5 years have normal cognitive function and 12 respondents $(38.7 \%)$ who suffer from hypertension for less than 5 years have decreased cognitive function. The results of statistical tests using chi-square showed $\mathrm{p}$ value of 0.009 at the value $=0.05$, it was concluded that there was a significant weak correlation $\mathrm{r}=$ 
0.287 between the duration of suffering from hypertension and cognitive function in the elderly. Analysis of relationships between variables has been included in Table 3.

Based on age, more elderly respondents aged $70-79$ years $(51.3 \%)$, compared to those aged 60-69 years $(26.3 \%)$ and at least aged over 80 years $(22.4 \%)$. Based on the level of education, there were more elementary school graduates, 36 people $(47.4 \%)$. This study shows that respondents with hypertension suffer from hypertension more than 5 years $(60.5 \%)$ (Table 2$)$. The same results were also obtained from Princess research on 50 respondents, found that more $(68 \%)$ of respondents suffered from hypertension $\geq 5$ years. [10] Research by Sari et al, states that this was caused by several factors, one of them being elderly who has a tendency to suffer from high blood pressure compared to at a young age, in addition to a decline in the function of organs including the heart. The results of the Mini Mental State Examination (MMSE) test showed more respondents experienced a decline in cognitive function, namely as many as 43 people (56.6\%) compared to 33 respondents who did not experience cognitive decline (normal) (43.4\%) (Table 3). According to Wreksoatmodjo, cognitive function is an intellectual component that plays an important role in determining the quality of one's life.

Hypertension could cause damage to the endothelium and cerebral arteries which cause interference in the blood vessels of the brain, causing a decrease in blood supply to the brain, atherosclerosis in large arteries and blockade of arterioles which causes damage to the alba substance. Damage to the alba substance shows worse cognitive results.[13] According to Ismaya et al. uncontrolled hypertension will make the smooth muscle cells of the blood vessels proliferate, resulting in increasingly narrow lumen and thicker blood vessel walls so that nutrients carried by blood to the brain tissue were also disrupted, eventually making the neuron cells die and cause cognitive impairment. [14] In this study data was obtained on the history of hypertension and the level of cognitive function through Mini Mental State Examination (MMSE) tests on respondents. Bivariate analysis with the chi square test shows the value of $\mathrm{p}=0.009$ which means there is a significant relationship and a weak correlation $r$ $=0.287$ between the history of the duration of hypertension and the decline in cognitive function, so the results obtained are in accordance with the hypothesis.

The results were accordance to the research conducted by the Princess in the Faculty of Medicine, University of North Sumatra with the number of respondents 50 people, showing $55.9 \%$ of respondents who suffer from hypertension $\geq 5$ years have decreased cognitive function. In the results of the study it was also found a significant relationship between the duration of hypertension and a decrease in cognitive function ( $p$ <0.004) .[10] The same results were found by Tuo et al, regarding the relationship of the duration of hypertension and changes in cognitive function in hypertensive patients. In this study, the duration of hypertension was divided into $\leq 5$ years, 6-10 years, 11-20 years and $>20$ years. It was found that compared to the normal group, the decline in cognitive function was significantly worse in the group with duration of hypertension> 20 years. [15] Another study conducted by Taufik found that a history of hypertension for more than 5 years caused a decline in cognitive function $(\mathrm{p}=0.001)$. It is said that someone who has hypertension who is left to remain high after 5 years will have a high risk of cognitive impairment.[16]

Hypertension was often associated with a decline in cognitive function, one of which is because an increase in blood pressure triggers lesions in the subcortical brain, leading to atherosclerosis, which causes thickening of the arterial wall and decreased permeability of blood vessel walls resulting in increased lipoprotein transport into the arterial wall. This causes decreased blood flow to the brain, the formation of lesions in brain tissue due to endothelial damage and cerebral blood flow insufficiency which is found in mild cognitive impairment. [17] 


\section{Conclusions}

The number of elderly respondents in the Elderly Posyandu in Puskesmas II Denpasar Barat Region who have a history of hypertension more than five years compared to those who suffer from hypertension for less than five years. Most of the elderly have a decline in cognitive function, compared to elderly who have normal cognitive function. There is a statistically significant relationship between the length of history of hypertension and the decline in cognitive function in the elderly at the Elderly Posyandu in the Public Health Center II in West Denpasar.

\section{References}

[1] Pandean GV, Surachmanto EE. 2014. Hubungan hipertensi dengan fungsi kognitif di Poliklinik SMF Ilmu Penyakit Dalam RSUP Prof. Dr. R. D. Kandou Manado. eClinic (eCl), Januari-Juni. Vol 4

[2] Dinas Kesehatan Provinsi Bali. 2015. Profil Kesehatan Provinsi Bali tahun.

[3] Kementerian Kesehatan RI. 2013. Laporan Hasil Riset Kesehatan Dasar (Riskesdas) 2013. Jakarta: Kementerian Kesehatan RI DinKes Jateng.

[4] Siringoringo M, Jemadi MK. 2014. Faktor-faktor yang berhubungan dengan hipertensi pada lansia di desa Sigaol Simbolon Kabupaten Samosir Tahun 2013 [pregraduate article].

[5] Myers, D G.2008. Social Psycology. Seven Edition.North America: McGraw-Hill, Inc

[6] Gaidhane S, Gaidhane AM, Zahiruddin OS, Khatib N. 2014. Essential hypertension and cognitive function in elderly. Global Journal of Medicine and Public Health Vol 3(2).

[7] Maryati H, Bhakti D.S, Dwiningtyas M. 2011. Gambaran fungsi kognitif pada lansia di UPT panti werdha mojopahit Kabupaten Mojokerto.

[8] Ramadian DA, S JMP, Runtuwene T. 2012. Gambaran Fungsi Kognitif pada Lansia di Tiga Yayasan Manula di Kecamatan Kawangkoan.

[9] Bandiyah, Siti. 2009. Lanjut Usia dan Keperawatan Gerontik. Yogyakarta : Nuha Medika.

[10] Puteri AE. 2015. Hubungan Lamanya Hipertensi dengan Gangguan Fungsi Kognitif Pada Lansia Di Posyandu Lansia Wilayah Puskesmas Padang Bulan Tahun 2015 [skripsi]. Medan (Indonesia): Universitas Sumatera Utara.

[11] Sari AP, Yusuf A, Wahyuni ED. 2015. Perubahan tekanan darah pada lansia dengan hipertensi melalui therapeutical gardening di UPT PSLU Magetan.

[12] Wreksoatmodjo BR. 2015. Aktivitas kognitif mempengaruhi fungsi kognitif lanjut usia di Jakarta. CDK-224. Vol 42.

[13] Guyton AC, Hall JE. 2011. Guyton and Hall Textbook of Medical Physiology. Vol 12; 203224.

[14] Ismaya MDRD, Kusumawati R, Murti B. 2015. Hubungan hipertensi dengan gangguan fungsi kognitif pada lansia di Posyandu Lansia Binaan Puskesmas Ngoresan Surakarta [skripsi]. Solo (Indonesia): Universitas Sebelas Maret.

[15] Tuo L, Yu B, Junwu X, Rui W, Jie B, Xiping T, et al. 2014. Duration of hypertension is associated with cognitive function: a crosssectional. Chinese Medical Journal. Vol 127 ; 2105 2110.

[16] Taufik ES, Purwoko Y, Muhartomo H. 2014. Pengaruh Hipertensi Terhadap Fungsi Kognitif Pada Lanjut Usia. Jurnal Media Medika Muda.

[17] Roberts RO, Geda YE, Knopman DS, Cha RH, Pankratz VS, Boeve BF. 2012. The incidence of mci differs by subtype and is higher in men: The Mayo Clinic Study of Aging. Neurology. Vol 78 (5): 342-51. 